\title{
Development and in vitro evaluation of extended-release theophylline matrix capsules
}

\author{
Vanessa Alves Pinheiro, Telma Mary Kaneko, Maria Valéria Robles Velasco, \\ Vladi Olga Consiglieri*
}

Departamento de Farmácia, Faculdade de Ciências Farmacêuticas, Universidade de São Paulo

*Correspondence:

V. O. Consiglieri

Departamento de Farmácia

Faculdade de Ciências Farmacêuticas

Universidade de São Paulo

Rua Lineu Prestes, 580, Bloco 13B

05508-900 - São Paulo - SP, Brazil

E-mail: siglieri@usp.br
Polymers like cellulose (Methocel ${ }^{T M}$ K100MPRCR, K15MPRCR and E4MCR) at different proportions (15-35\%) were used to slow the release of theophylline $(100 \mathrm{mg})$ from capsules. Volumetric method for powder filling capsules was used to prepare the capsules. Drug release from capsules was performed using apparatus 1, at $100 \mathrm{rpm}$ and $900 \mathrm{~mL}$ of intestinal medium without enzymes ( $p H 7.5)$, at $37^{\circ} \mathrm{C}$, following the USP 28 th ed. (Test 8). Dissolution profiles were compared to two batches of commercial extended-release capsules. Capsules compounded with 35\% (wt) wt) of Methocel ${ }^{T M}$ E4MCR showed dissolution profile according to the official especifications. Similar results were reproduced with other ten compounded batches. Commercial extended-release capsules containing theophylline pellets (100 mg) showed quick drug release when submitted to the same test, indicating that, in these conditions, the capsules did not show prolonged release. Mathematical models like zero-order, first-order and Higuchi were applied in kinetic studies of theophylline release from the compounded capsules. Polymers were efficient to control the release of theophylline in capsules involving diffusion and erosion as mechanisms, and that first-order model was the best fitted one for theophylline matrix capsules. These results support that compounded extended-release capsules can be prepared, since the drug release tests can be done.

\section{INTRODUCTION}

Compounded capsules have some advantages, like adjusting the dosage to the therapeutic patient needs, considering weight, therapeutic objective and side effects. When patients require specific individualized therapy, pharmacists are called upon by physicians to compound a
Uniterms

- Theophylline

- Capsules

- Extended-release

- Dissolution wide range of different products, including extendedrelease and slow-release capsules (Bogner, Szwejkowski, Houston, 2001).

The modified release term has been used to describe many kinds of therapeutic and/or pharmacokinetic objectives, including sustained-release, sustained action, prolonged action, slow-release, delayed-release, etc 
(Shargel, Yu, 1999). Extended-release dosage forms have been extensively carried out several decades ago. Production of tablets and capsules with microgranules has been described applying various materials as cellulose and methacrylic acid derivatives (McGinity, Fukuda, Peppas, 2006; Zheng, Sauer, McGinity, 2005; Lopes, Costa, Lobo, 2005; Fu et al., 2004; McGinity et al., 2004; Young, Koleng, McGinity, 2002; Siepmann et al., 2000; Ishikawa et al., 2000)

Compounded, slow-release and extended-release capsules has been part of a group called matrix systems and the most common technique to obtain these matrices involves basically the simple mixture of the drug with an inert, hydrophobic or hydrophilic matrix that can be encapsulated (Ojantakanen et al., 1993).

There are few published researches with compounded matrix capsules. Webster, Al-AlChi, Greenwood (1999) studied dissolution profiles of slow-release capsules with morphine sulfate. These authors claimed that these capsules can be an adequate alternative for the administration of morphine sulfate, based on its release, similar to that of the commercial medications.

In another study with morphine sulfate, the authors got six slow-release capsules formulations with $300 \mathrm{mg}$ dose, prolonging the release with HPMC K100M polymer (Bogner, Szwejkowski, Houston, 2001).

Hydrophilic matrix capsules were also studied with micronized hormones, like progesterone, HPMC E4M Premium and excipients. They were mixed and compacted in gelatin hard capsules. It was concluded that the use of slow-release matrices prolonged the hormone absorption for many hours, allowing the patient to decrease the dose frequency. However, the authors reported the necessity of further pharmacokinetic studies, without which no affirmation could be made about the bioidentical hormones release profiles from slow-release capsules (Timmons, Timmons, 2002).

Theophylline is a good candidate to be encapsulated in slow-release capsules, since the treatment of obstructive chronic pulmonary disease and night crisis depend on keeping seric levels of the drug constant. This explains the existence of a large number of studies about modified release dosage forms with theophylline (Vendruscolo et al., 2005; Zheng, Sauer, McGinity, 2005; McGinity et al., 2005; Ojoe et al., 2005; Chambin et al., 2004; Young, Koleng, McGinity, 2002; Pather et al., 1998).

In spite of these works, there are no studies that prove the compounded extended-release capsules can reduce the drug release in accordance to the official requirements and also present inter-batch uniformity on the drug release profiles.
This research had the purpose of obtaining slowrelease compounded capsules with theophylline $100 \mathrm{mg}$ dose, using cellulose derivatives in different rates, studying the "in vitro" drug release. Results were compared to the theophylline release from brand medication (capsules with microgranules). Reproducibility of theophylline release from different batches of capsules was also studied.

\section{MATERIAL AND METHODS}

The following materials of pharmaceutical grade were used to compound matrix capsules: anhydrous theophylline $99.80 \%$ (supplied by Ariston), hydroxypropylmethylcellulose - Methocel $^{\mathrm{TM}}$ K100MPRCR, E4MCR and K15MPRCR (Dow Chemical $^{\mathrm{TM}}$ ), lactose M200 (Galena ${ }^{\mathrm{TM}}$ ). Gastric fluid ( $\mathrm{pH}$ 1.2) and intestinal fluid (pH 7.5) were prepared, according to United States Pharmacopeia, 28th ed. (2005), with Merck analytic grade reagents. Anhydrous theophylline $99.80 \%$ was used for analytical determinations. Colourless, number size 1 capsules (Cardinal Health ${ }^{\mathrm{TM}}$ ).

\section{Commercial capsules with prolonged-release microgranules (same manufacturer).}

Laboratory B1 (Brand Medication): capsules with $100 \mathrm{mg}$ of prolonged-release theophylline microgranules, batch Z95429; fabrication: 06/2003; beyond-use date: 06/ 2006;

Laboratory B2 (Brand Medication): capsules with $100 \mathrm{mg}$ of prolonged-release theophylline microgranules, batch Z100857; fabrication: 01/2004; beyond-use date: $12 /$ 2006;

\section{Formulations}

Six different slow-release formulations of capsules with $100 \mathrm{mg}$ of theophylline were prepared, using volumetric method for powder filling capsules in a manual encapsulator (Multilabor ${ }^{\mathrm{TM}}$ ) (Allen, 1999). The composition of the compounded capsules is presented on the Table I.

All the components were sieved in $0.090 \mathrm{~mm}$ sieve (170 mesh). The drug and the polymer were then weighted. Their apparent volumes were measured in a graduated cylinder $(50 \mathrm{~mL})$ and the powders were settled down. The graduated cylinder was gently tapped 10 times and was filled with lactose as excipient. The powders were mixtured in a plastic bag for 10 minutes. All the powder was homogenized another 10 minutes in a mortar. 
TABLE I - Composition of compounded extended-release capsules with $100 \mathrm{mg}$ of theophylline and hydroxypropylmethylcellulose (HPMC, Methocel $^{\mathrm{TM}}$ K100MPRCR, K15MPRCR e E4MCR), using volumetric method for powder filling capsules in batches of 50 .

\begin{tabular}{|c|c|c|c|c|c|c|c|c|c|c|c|c|}
\hline \multirow[t]{2}{*}{ Powder material } & \multicolumn{2}{|c|}{ MEK100M1 } & \multicolumn{2}{|c|}{ MEK100M2 } & \multicolumn{2}{|c|}{ MEK100M3 } & \multicolumn{2}{|c|}{ MEK15M1 } & \multicolumn{2}{|c|}{ MEE4M1 } & \multicolumn{2}{|c|}{ MEE4M351 } \\
\hline & (mg) & $(\%)$ & (mg) & $(\%)$ & $(\mathrm{mg})$ & $(\%)$ & $(\mathrm{mg})$ & $(\%)$ & $(\mathrm{mg})$ & $(\%)$ & $(\mathrm{mg})$ & $(\%)$ \\
\hline Theophylline & 100.0 & 57.14 & 100.0 & 48.78 & 100.0 & 41.32 & 100.0 & 37.45 & 100.0 & 37.45 & 100.0 & 37.45 \\
\hline Methocel $^{\mathrm{TM}} \mathrm{K} 100 \mathrm{M}$ & 75.0 & 42.86 & 50.0 & 24.39 & 37.4 & 15.46 & 0.00 & 0.00 & 0.00 & 0.00 & 0.00 & 0.00 \\
\hline Methocel ${ }^{\mathrm{TM}} \mathrm{K} 15 \mathrm{M}$ & 0.00 & 0.00 & 0.00 & 0.00 & 0.00 & 0.00 & 75.0 & 28.09 & 0.0 & 0.00 & 0.00 & 0.00 \\
\hline Methocel $^{\mathrm{TM}} \mathrm{E} 4 \mathrm{M}$ & 0.00 & 0.00 & 0.00 & 0.00 & 0.00 & 0.00 & 0.00 & 0.00 & 75.0 & 28.09 & 87.4 & 32.73 \\
\hline Lactose & 0.00 & 0.00 & 55.0 & 26.83 & 104.6 & 43.22 & 92.0 & 34.46 & 92.0 & 34.46 & 79.6 & 29.82 \\
\hline Total & 175.0 & 100.0 & 205.0 & 100.0 & 242.0 & 100.0 & 267.0 & 100.0 & 267.0 & 100.0 & 267.0 & 100.0 \\
\hline
\end{tabular}

The powders were carefully spread on the manual encapsulator until the content was completely inside the capsules, and were settled down by tapping the manual encapsulator 10 times. The caps were put over the capsules bodies and locked. Fifty capsules of each batch were prepared.

\section{Weight variation}

Twenty capsules of each formulation were individually weighted and average, standard deviation and variation coefficient were calculated. The results were compared to the specifications of USP 28th ed. (2005).

\section{Assay}

An in-house spectrophotometric validated method, in $\mathrm{pH} 7.5$ phosphate buffer solution, at $271 \mathrm{~nm}$, was used to quantify the theophylline in the capsules. Samples of powders, corresponding to $100 \mathrm{mg}$ of theophylline were taken and transferred to a volumetric flask $(100.0 \mathrm{~mL})$. About $50 \mathrm{~mL}$ of ethylic alcohol were added and the volumetric flask was sonicated for 40 minutes. The volume was completed with ethylic alcohol. The solution was centrifugated for 20 minutes and aliquots of $1 \mathrm{~mL}$ were taken and diluted into a $100.0 \mathrm{~mL}$ volumetric flask with 7.5 $\mathrm{pH}$ simulated intestinal fluid.

Sample solutions were recorded in a Beckman Coulter, DU 640, spectrophotometer at $271 \mathrm{~nm}$, in comparison with $10 \mu \mathrm{g} / \mathrm{mL}$ theophylline standard solution, in the same medium. The tests were performed in duplicate.

\section{Drug release}

The following test was performed according to American Pharmacopeia 28th ed., for Theophylline Extended-Release Capsules Test 8, using apparatus 1 (basket) with $100 \mathrm{rpm}$ stirring and temperature of $37^{\circ} \mathrm{C} \pm$ $0.5^{\circ} \mathrm{C}$. A $7.5 \mathrm{pH}$ simulated intestinal fluid (without enzyme) was used as medium (United States Pharmacopeia, 2005).

Aliquots of $10 \mathrm{~mL}$ were withdrawn in different times $(15,30,45,60,90,120,180,240,300,360,420$ and 480 minutes) from the beginning of the test and the medium was replaced with equal volume at the same temperature. The aliquots were then centrifuged, diluted and quantified by ultraviolet spectrophotometric analysis, using a Standard solution with a known concentration of theophylline in the same medium as reference.

\section{Model dependent parameters}

Three mathematics models were applied to interpret dissolution kinetic, in order to determine the process order: first-order model, zero-order model and Higuchi model (Abdou, Hanna, Muhammad, 2000; Ferraz, Consiglieri, Storpirtis, 1998; Shah, Noory, Noory, 1995)

\section{Dissolution Efficiency}

Dissolution efficiency (DE) was graphically calculated from dissolved drug percentage versus time curves (Khan, Rhodes, 1975). Variance analysis (ANOVA) was used to check the existence of significant differences between DE data.

\section{Model independent parameters}

Data from dissolution profiles of chosen batches and the brand medication (Laboratory B) were submitted to simple independent model employing a difference factor (f1) and a similarity factor (f2) to compare the dissolution profiles (Costa, 2001; Shah et al., 1998). 


\section{RESULTS AND DISCUSSION}

Official specifications establish that, for hard capsules up to $300.0 \mathrm{mg}$, the weight variation allowed is \pm $10.0 \%$, and it is not allowed more than two units out of the specification and none of them can be above or under the double of the indicated percentage. The results of weight variation presented in the Tables II and III showed that all the capsules complied with the Pharmacopeia specifications (United States Pharmacopeia, 2005).

The compounded capsules showed theophylline amount between $94.6 \%$ and $101.22 \%$, and those from the commercial batches B1 and B2 showed 104.45\%,

TABLE II - Results of weight variation and assay of compounded extended-release capsules with $100 \mathrm{mg}$ of theophylline

\begin{tabular}{lcc}
\hline $\begin{array}{l}\text { Products } \\
\text { (Batches) }\end{array}$ & $\begin{array}{c}\text { Weight } \\
\text { variation }(\mathrm{mg}) \\
(\mathrm{CV} \%)^{*}\end{array}$ & $\begin{array}{c}\text { Assay } \\
(\%)\end{array}$ \\
\hline MEK100M1 & $176.93(3.87)$ & 97.84 \\
MEK100M2 & $205.02(2.57)$ & 99.02 \\
MEK100M3 & $242.51(2.50)$ & 100.41 \\
MEK15M1 & $254.69(2.91)$ & 94.60 \\
MEE4M1 & $257.44(2.13)$ & 99.61 \\
MEE4M351 & $271.91(1.87)$ & 100.30 \\
MEE4M352 & $270.47(1.97)$ & 100.76 \\
MEE4M353 & $274.70(1.51)$ & 99.40 \\
MEE4M354 & $275.16(1.56)$ & 100.85 \\
MEE4M355 & $270.14(2.88)$ & 101.22 \\
MEE4M356 & $274.59(1.76)$ & 99.12 \\
MEE4M357 & $274.14(2.36)$ & 99.08 \\
MEE4M358 & $273.71(1.22)$ & 100.98 \\
MEE4M359 & $272.75(1.83)$ & 100.42 \\
MEE4M3510 & $274.51(1.91)$ & 100.67 \\
\hline
\end{tabular}

*Coefficient of Variation; $\mathrm{CV}=\mathrm{n}=20$ determinations.

TABLE III - Results of weight variation and assay of commercial capsules with $100 \mathrm{mg}$ of prolonged-release theophylline microgranules

\begin{tabular}{lcc}
\hline $\begin{array}{l}\text { Product } \\
\text { (Laboratories) }\end{array}$ & $\begin{array}{c}\text { Weight } \\
\text { variation (mg) } \\
(\mathrm{CV} \%)\end{array}$ & $\begin{array}{c}\text { Assay } \\
(\%)\end{array}$ \\
\hline B1 (brand medication) & $161.76(1.17)^{*}$ & 102.38 \\
B2 (brand medication) & $154.56(1.80)^{*}$ & 104.45 \\
\hline
\end{tabular}

$\mathrm{CV}=$ Coefficient of Variation; $\mathrm{CV}=\mathrm{n}=10$ determinations; $\mathrm{CV}^{*}=\mathrm{n}=5$ determinations. respectively, therefore in accordance with the official specifications (United States Pharmacopeia, 2005) (Tables II and III).

The three types of tested Methocel ${ }^{\mathrm{TM}}$ showed decrease of theophylline release from the capsules (Figures 1 and 2).

According to the dissolution profiles results, the increase of HPMC content, as well as the use of higher viscosity polymers in the formulations, resulted in the decrease of theophylline dissolution rate in compounded capsules. The capsules from the formulation MEE4M351, with $35 \%$ (wt/wt) of Methocel ${ }^{\mathrm{TM}} \mathrm{E} 4 \mathrm{MCR}$, presented dissolved amount of theophylline in accordance with the specifications of American Pharmacopeia 28th ed, Test 8.

From this formulation, ten batches were compounded to check the reproducibility of the process (Figure 2). All the batches showed dissolved quantities of theophylline in accordance with the specified limits (United States Pharmacopeia, 2005).

When the dissolution profiles of the ten batches of the formulation MEE4M351 and the brand medication (Laboratory B1) were compared through the independent model employing difference factor (f1) and similarity factor (f2), it was possible to verify that $\mathrm{fl}$ values above 15 and f2 values under 50 were obtained. This means that the compounded formulations showed different dissolution profiles when compared to the studied commercial products (Table IV).

To analyze the variance among the average values of Dissolution Efficiency (DE) obtained from chosen developed batches (Figure 3), the Variance Analysis "ANOVA: Unique Factor" was used . This tool performed a simple variance analysis, in order to check if there was significant difference among the values of DE.

TABLE IV - Results of difference factor (f1) and similarity factor (f2) to compare the dissolution profiles

\begin{tabular}{lcc}
\hline $\begin{array}{l}\text { Compounded } \\
\text { batches }\end{array}$ & $\begin{array}{l}\text { Difference } \\
\text { factor (f1) }\end{array}$ & $\begin{array}{l}\text { Similarity } \\
\text { factor (f2) }\end{array}$ \\
\hline MEE4M351 & 52.69 & 23.25 \\
MEE4M352 & 52.73 & 23.32 \\
MEE4M353 & 51.85 & 23.62 \\
MEE4M354 & 53.92 & 22.72 \\
MEE4M355 & 51.86 & 22.86 \\
MEE4M356 & 51.73 & 23.43 \\
MEE4M357 & 50.23 & 23.64 \\
MEE4M358 & 49.05 & 24.03 \\
MEE4M359 & 53.76 & 22.76 \\
MEE4M3510 & 54.64 & 22.50 \\
\hline
\end{tabular}




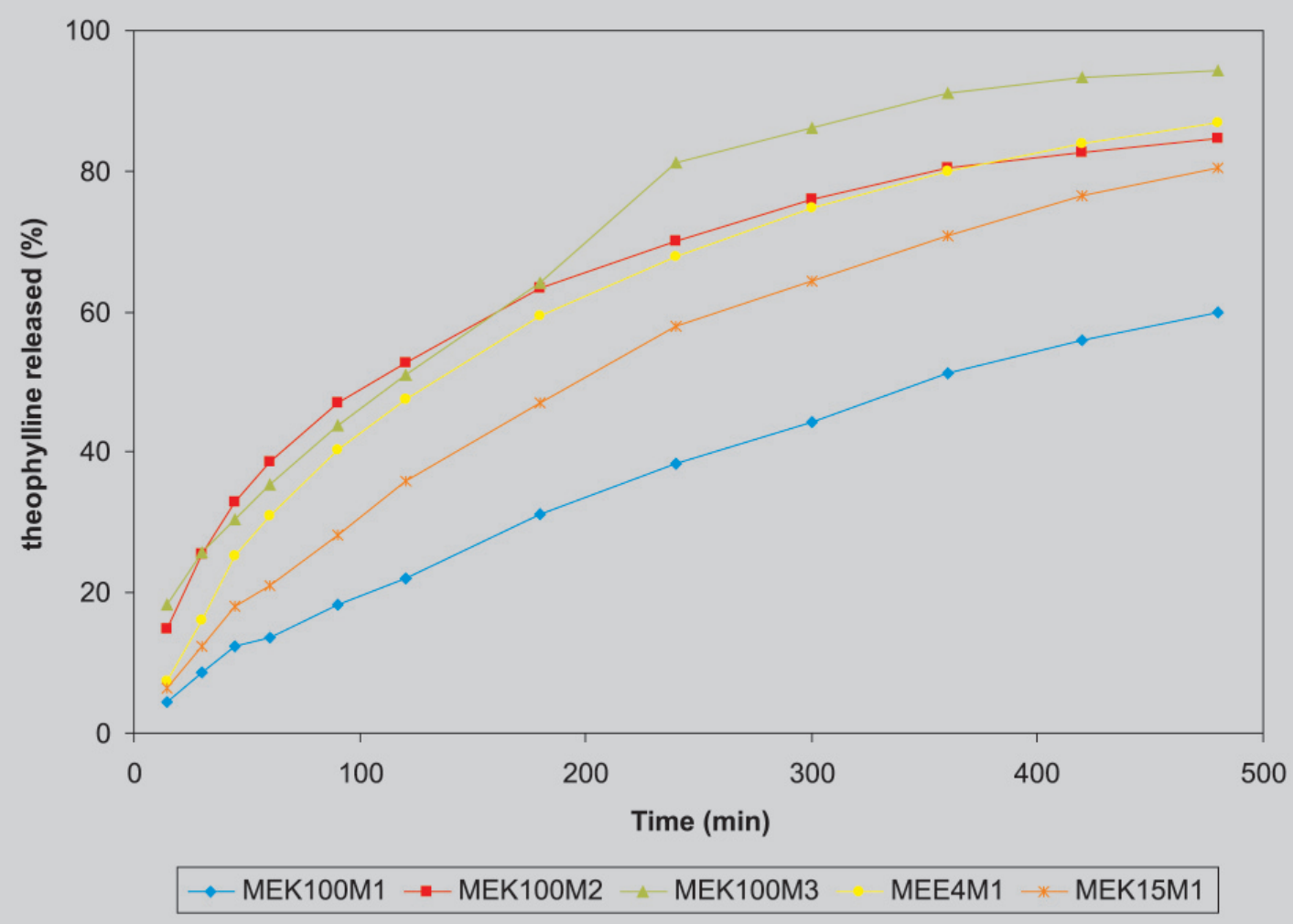

FIGURE 1 - Release profiles of theophylline capsules with Methocel $^{\mathrm{TM}}$ K100MPRCR, K15MPRCR and E4MCR.

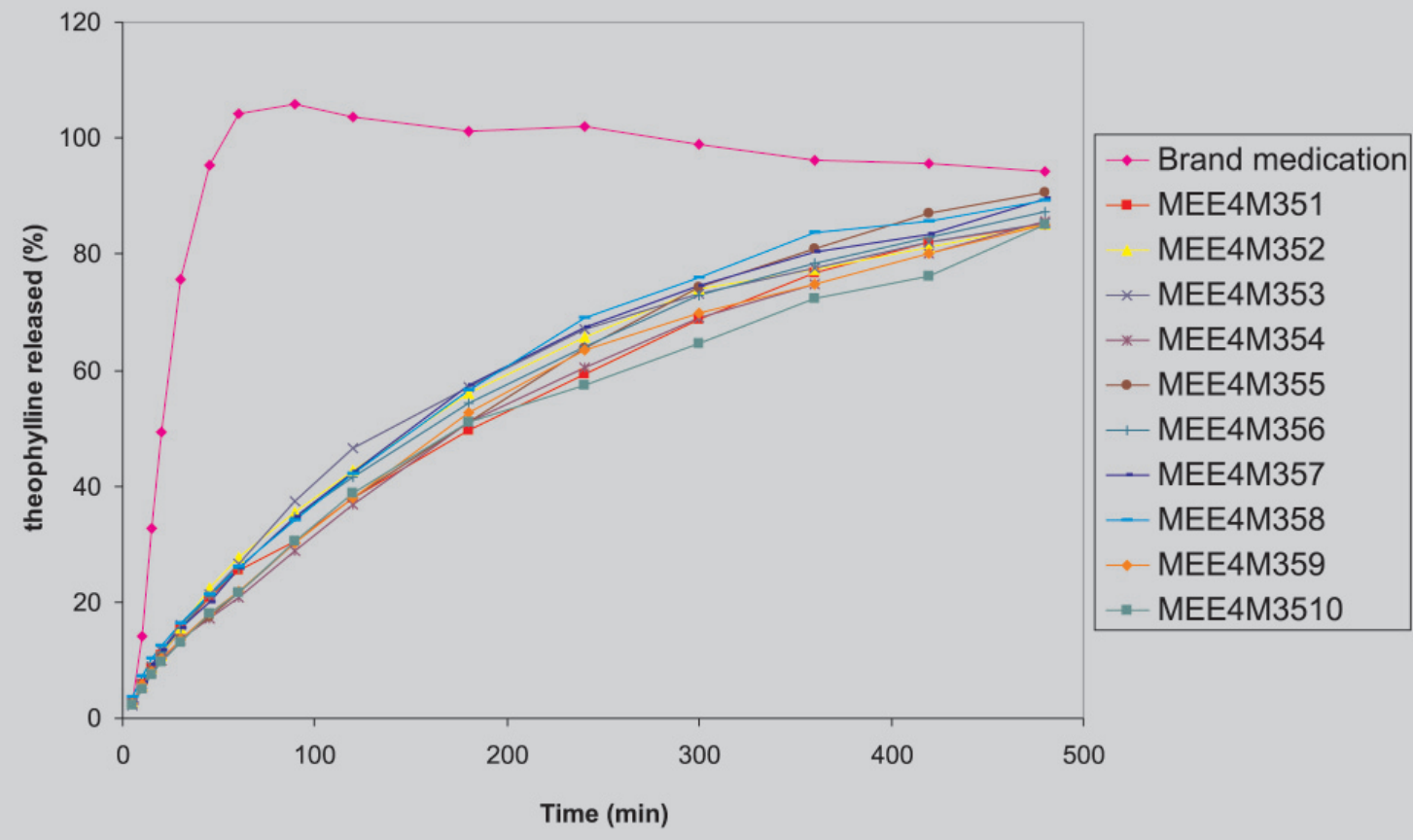

FIGURE 2 - Release profiles of theophylline capsules with Methocel ${ }^{\mathrm{TM}} \mathrm{E} 4 \mathrm{MCR}$ and Brand medication. 


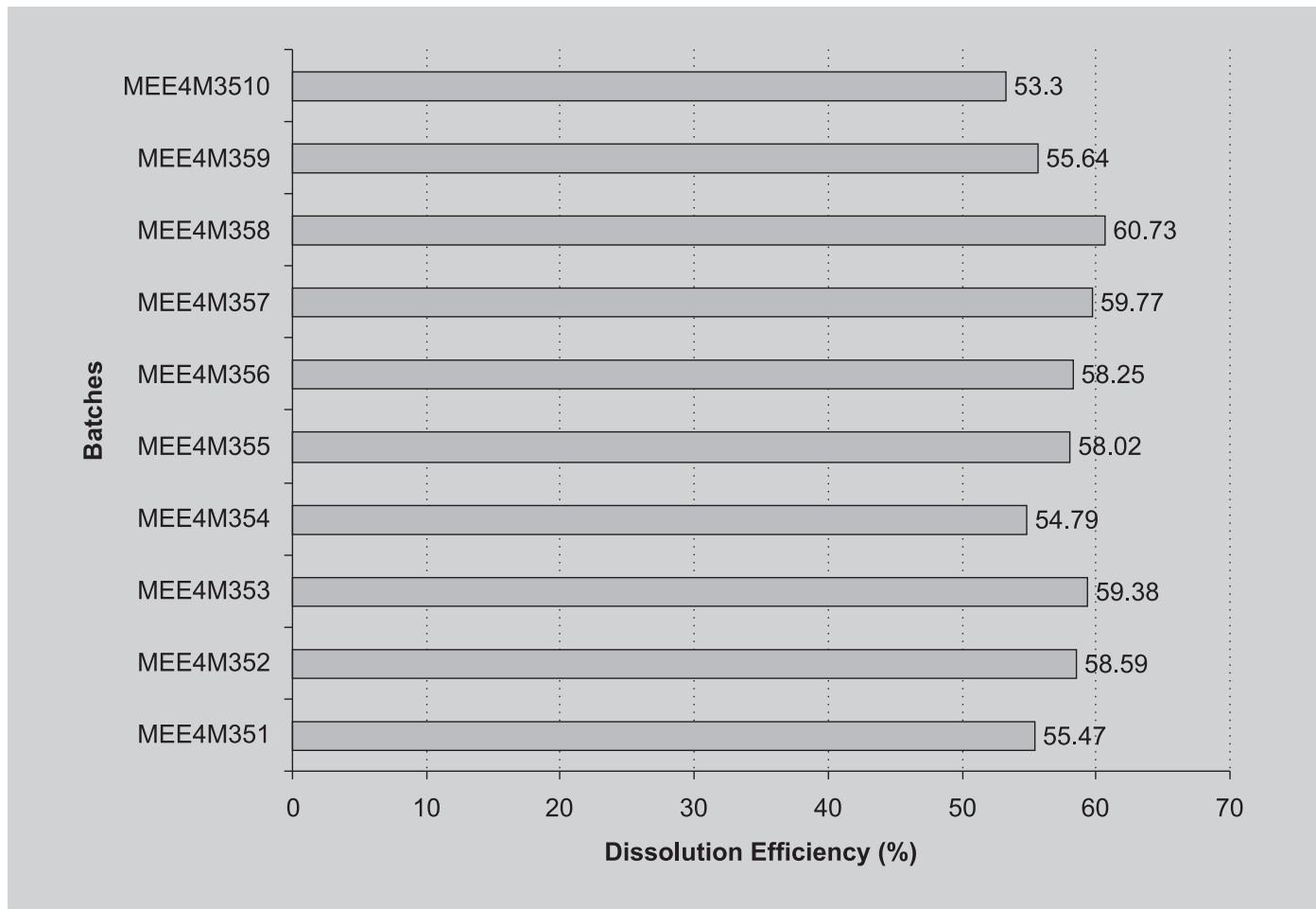

FIGURE 3 - Medium values of DE (\%) for compounded batches.

In this case, it was assumed as null hypothesis that the average of two ou more samples are equals (from population with the same average).

According to Table $\mathrm{V}$, the found value of $\mathrm{F}$ was 2.07, and the value of $\mathrm{F}$ necessary to $5 \%$ significance is 2.12 . Therefore, there is no significant difference among the compounded batches.

The kinetic models most adequated to the preparations and the obtained values for the correlation coefficient (r) of the compounded formulations are described in Table VI.

According to the correlation coefficients observed, excepted the formulation MEE4M3510, the reproduced batches followed first-order kinetic process, indicating that the dissolution rate of solid particles in a liquid medium depends of the relation between the dissolved amount of drug and the remaining amount of it in the matrix. This means that, possibly, the process occurs as a result of the drug diffusion through the jelly layer and the erosion of the matrix system, process known as Non-Fickian or anomalous.

Only the formulation MEE4M3510, with a correlation coefficient of 0.9925 , followed the Higuchi model, in which the quantity of drug released is directly proportional to the " $t$. In fact, it was not expected that the release followed the Higuchi model, since this model considers the drug release as a diffusion process based on the first law of Fick, not considering other mechanisms, like drug release by erosion.

In the systems that employ hydrophilic matrices to control slightly soluble drug release, the predominant mechanism is generally erosion (Sako et al., 2002). In the

TABLE V - Analysis of variance (ANOVA) of Dissolution Efficiency (DE) results of each studied batch

\begin{tabular}{lcccc}
\hline Source Of Variation & Degrees of Freedom & Sum of Squares & Mean Square & F \\
\hline Between groups & 9 & 268.025 & 29.781 & $2.07^{*}$ \\
Within groups & 40 & 576.189 & 14.405 & \\
Total & 49 & 844.214 & & \\
\hline
\end{tabular}

$* p=0.0563$ 
TABLE VI - Correlation coefficients (r) obtained from mathematical treatment of dissolution kinetics data.

\begin{tabular}{lcccc}
\hline Formulations & Zero-order & First-order & Higuchi & Models \\
\hline MEE4M351 & 0.9584 & 0.9975 & 0.9939 & First-order \\
MEE4M352 & 0.9254 & 0.9951 & 0.9906 & First-order \\
MEE4M353 & 0.9173 & 0.9941 & 0.9888 & First-order \\
MEE4M354 & 0.9600 & 0.9987 & 0.9901 & First-order \\
MEE4M355 & 0.9659 & 0.9936 & 0.9879 & First-order \\
MEE4M356 & 0.9422 & 0.9993 & 0.9935 & First-order \\
MEE4M357 & 0.9388 & 0.9973 & 0.9912 & First-order \\
MEE4M358 & 0.9411 & 0.9975 & 0.9905 & First-order \\
MEE4M359 & 0.9511 & 0.9987 & 0.9899 & First-order \\
MEE4M3510 & 0.9555 & 0.9914 & 0.9925 & Higuchi \\
\hline
\end{tabular}

case of compounded slow-release capsules, besides this consideration, it must be remembered that due to low compaction, the jelly layer formed by Methoce ${ }^{\mathrm{TM}}$ when in contact with the medium tends to be less rigid than one provided from a formulation with the same polymer in tablets dosage forms, due to a higher porosity of the capsule (Bogner, Szwejkowski, Houston, 2001), meeting the firstorder model found.
In the dissolution profiles of the commercial capsules with prolonged release of $100 \mathrm{mg}$ theophylline microgranules, it was showed that the formulations presented quick release of the drug, with dissolved amount of theophylline percentage of $104.28 \%$ in 60 minutes and $97.18 \%$ in 60 minutes (Figure 4), indicating that in these formulations the drug release is not a limit factor to the absorption. They did not complied with the specifications of the Test 8 (United States Pharmacopeia, 2005).

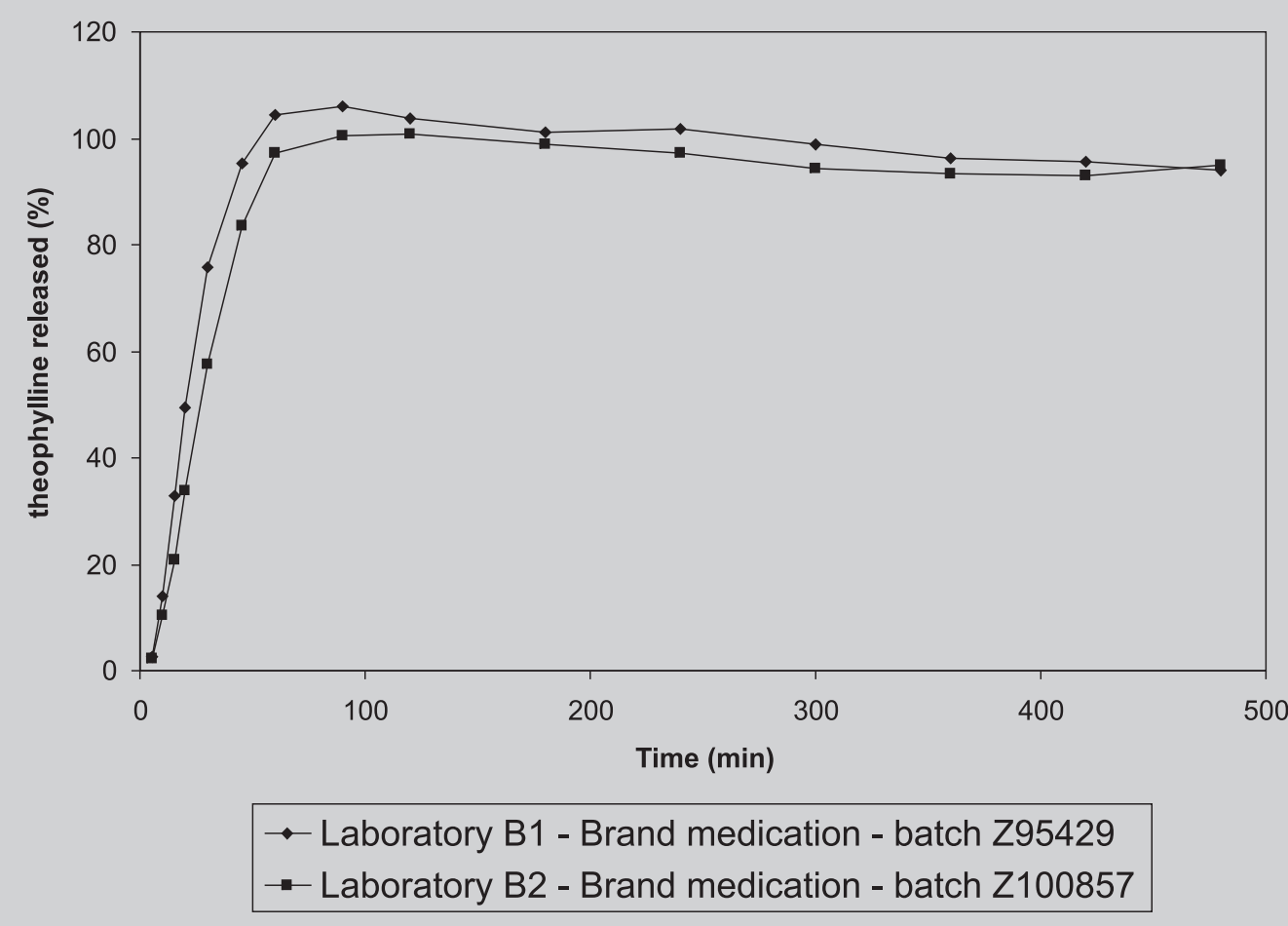

FIGURE 4 - Release profiles of commercial capsules with prolonged release of $100 \mathrm{mg}$ theophylline microgranules. 


\section{CONCLUSION}

It was possible to obtain compounded modified release matrix capsules with theophylline using different types of hydroxypropylmethylcellulose, like Methocel ${ }^{\mathrm{TM}}$ K100MPRCR, Methocel ${ }^{\mathrm{TM}}$ K15MPRCR and Methocel ${ }^{\mathrm{TM}}$ E4MCR, to decrease the drug release rate. The formulation with $35 \%$ (wt/wt) of Methocel ${ }^{\mathrm{TM}} \mathrm{E} 4 \mathrm{MCR}$ was the one which met the specifications of dissolved drug percentage. Also, it is possible to obtain reproducibility of dissolved drug percentage in extended-release compounded capsules.

\section{RESUMO}

\section{Desenvolvimento e avaliação in vitro de cápsulas de teofilina de liberação prolongada}

Cápsulas de liberação modificada contendo $100 \mathrm{mg}$ de teofilina foram preparadas com polímeros derivados da celulose (Methocel ${ }^{\circledR}$ K100MPRCR, K15MPRCR e $E 4 M C R)$ em diferentes concentrações, 15-35\%, empregando-se o método volumétrico. Estudos de liberação do fármaco foram realizados de acordo com a Farmacopéia Americana 28 ed., (Teste 8), empregando aparato 1, rotação de $100 \mathrm{rpm}$ e temperatura de $37^{\circ} \mathrm{C} \mathrm{em} 900 \mathrm{~mL}$ de meio fluido intestinal sem enzimas $(p H 7,5)$. Os perfis de dissolução foram comparados ao de duas especialidades farmacêuticas comerciais. A formulação, com $35 \%$ de Methocel ${ }^{\circledR}$ E4MCR, evidenciou perfis de liberação de acordo com as especificações e os resultados foram reprodutiveis para 10 lotes manipulados com a mesma formulação. As cápsulas comerciais de liberação prolongada contendo $100 \mathrm{mg}$ de teofilina (microgrânulos), submetidas ao mesmo ensaio, apresentaram rápida liberação do fármaco, indicando que a liberação não é fator limitante para a absorção. Avaliou-se a cinética de liberação do fármaco empregando os modelos matemáticos de ordem zero, primeira ordem e Higuchi. Conclui-se que as matrizes obtidas foram capazes de modular a liberação, envolvendo os mecanismos de difusão e erosão, prevalecendo o modelo de primeira ordem e que as cápsulas de liberação modificada podem ser manipuladas, desde que testes de liberação sejam realizados.

UNITERMOS: Teofilina. Cápsulas. Liberação prolongada. Dissolução.

\section{ACKNOWLEDGMENTS}

The authors would like to thank Colorcon ${ }^{\mathrm{TM}}$ and Blanver $^{\mathrm{TM}}$, São Paulo, Brazil, for the raw-materials.

\section{REFERENCES}

ABDOU, H.M.; HANNA, S.; MUHAMMAD, N. Dissolution. In: GENNARO, A.R. Remington: The science and practice of pharmacy. 20.ed. Baltimore: Lippincott Willians \& Wilkins, 2000. cap.35, p.654-666.

ALLEN, L.V. Basics of compounding: compounding powderfilled capsules, The. Int. J. Pharm. Compd., v.3, n.3, p.209-215, 1999.

BOGNER, R.H.; SZWEJKOWSKI, J.; HOUSTON, A. Release of morphine sulfate from compounded slowrelease capsules: the effect of formulation on release. Int J. Pharm. Compd., v.5, n.5, p.401-405, 2001.

CHAMBIN, O.; CHAMPION, D.; DEBRAY, C.; ROCHATGONTHIER, M.H.; LÊ MESTE, M.; POUCELOT, Y. Effects on different cellulose derivatives on drug release mechanism studied at a preformulation stage. J. Control. Release, v.95, p.101-108, 2004.

COSTA, P. An alternative method to the evaluation of similarity factor in dissolution testing. Int. J. Pharm., v.220, n.1/2, p.77-83, 2001.

FERRAZ, H.G.; CONSIGLIERI, V.O.; STORPIRTIS, S. Avaliação da cinética de dissolução de ampicilina em comprimidos comercializados no Brasil. Rev. Farm. Bioquim. Univ. São Paulo, v.34, n.2, p.93-99, 1998.

FU, X.C.; WANG, G.P.; LIANG, W.Q.; CHOW, M.S.S. Prediction of drug release from HPMC matrices: effect of physicochemical properties of drug and polymer concentration. J. Control. Release, v.95, p.209-216, 2004.

ISHIKAWA, T.; WATANABLE, Y.; TAKAYAMA, K.; ENDO, H.; MATSUMOTO, M. Effect of HPMC on the release profiles and bioavailability of a poorly watersoluble drug from tablets prepared using macrogol and HPMC. Int. J. Pharm., v.202, p.173-178, 2000.

KHAN, K.A.; RHODES, C.T. The concept of dissolution efficiency. J. Pharm. Pharmacol., v.27, p.48-49, 1975.

LOPES, C.M.; LOBO, J.M.S.; COSTA, P. Formas farmacêuticas de liberação modificada: polímeros hidrifilicos. Rev. Bras. Cienc. Farm., v.41, n.2, p.143-154, 2005. 
MCGINITY, J.W.; CROWLEY, M.M.; SCHROEDER, B.; FREDERSDORF, A.; OBARA, S.; TALARICO, M.; KUCERA, S. Physicochemical properties and mechanism of drug release from ethyl cellulose matrix tablets prepared by direct compression and hot-melt extrusion. Int. J. Pharm., v.269, p.509-522, 2004.

MCGINITY, J.W.; YOUNG, C.R.; DIETZSCH, C.; CEREA, M.; FARRELL, T.; FEGELY, K.A.; RAJABISIAHBOOMI, A. Physicochemical characterization and mechanisms of release of theophylline from melt-extruded dosage forms based on a methacrylic acid copolymer. Int . J. Pharm., v.301, p.112-120, 2005.

MCGINITY, J.W.; FUKUDA, M.; PEPPAS, N.A. Properties of sustained-release hot-melt extruded tablets containing chitosan and xanthan gum. Int. J. Pharm., v.310, p.90100, 2006.

OJANTAKANEN, S.; MARVOLA, M.; HANNULA,A.M.; KLINGE, E.; NAUKKARINNEN, T. Bioavailability of ibuprofen from hard gelatin capsules containing different viscosity grades of hydroxypropylmethylcellulose and sodium carboxymethylcellulose. Eur. J. Pharm. Sci., v.1, p.109-114, 1993.

OJOE, E.; MIYAUCHI, E.M.; VIVIANE, T.C.; CONSIGLIERI, V.O. Formulation and in vitro evaluation of theophylline Eudragit sustained-release tablets. Rev. Bras. Ciênc. Farm., v.41, n.3, p.377-384, 2005.

PATHER, S.I.; RUSSELL, I.; SYCE, A.J.; NEAU, S.H. Sustained release theophylline tablets by direct compression. Part 1. Formulation and in vitro testing. Inter. J. Pharm., v.164, p.1-10, 1998.

SAKO, K.; SAWADA, T.; NAKASHIMA, H.; YOKOHAMA, S.; SONOBE, T. Influence of water soluble fillers in hydroxypropylmethylcellulose matrices on in vitro and in vivo drug release. J. Control. Release, v.81, p.165-172, 2002.

SHAH, V.P.; NOORY, A.; NOORY, C. In vitro dissolution of sparingly water-soluble drug dosage forms. Int. J. Pharm., v.125, p.99-106, 1995.
SHAH, V.P.; TSONG, Y.; SATHE, P.; LIU, J. In vitro dissolution profile comparison - statistics and analysis of the similarity factor, f. Pharm. Res., v.15, p.889-896, 1998.

SHARGEL, L.; YU, A.B.C. Applied biopharmaceutics and pharmacokinetics. 4.ed. New York: McGraw-Hill, 1999. $768 \mathrm{p}$.

SIEPMANN, J.; KRANZ, H.; PEPPAS, N.A.; BODMEIER, R. Calculation of required size and shape of HPMC matrices to achieve desired drug release profiles. Int. J. Pharm., v.201, p.151-154, 2000.

TIMMONS, E.D.; TIMMONS, S.P. Custom-compounded micronized hormones in a slow-release capsule matrix. Int. J. Pharm. Compd., v.6, n.5, p.378-379, 2002.

UNITED States Pharmacopeia. 28.ed. Rockville: United States Pharmacopeial Convention, 2005. p.1685-1686.

VENDRUSCOLO, C.W.; ANDREAZZA, I.F.; GANTER, J.L.M.S.; FERRERO, C.; BRESOLIN, T.M.B. Xanthan and galactomannan (from M. scabrella) matrix tablets for oral controlled delivery of theophylline. Int. J. Pharm., v.296, p.1-11, 2005.

WEBSTER, K.D.; AL-ALCHI, A.; GREENWOOD, R. In vitro studies on the release of morphine sulfate from compounded slow-release morphine-sulfate capsules. Int . J. Pharm. Compd., v.3, n.5, p.409-411, 1999.

YOUNG, C.R.; KOLENG, J.J.; MCGINITY, J.W., Production of spherical pellets by a hot-melted extrusion and spheronization process. Int. J. Pharm., v.242, p.8792, 2002.

ZHENG, W.; SAUER, D.; MCGINITY, J.W. Influence of hydroxyethylcellulose on the drug release properties of theophylline pellets coated with Eudragit ${ }^{\circledR}$ RS 30 D. Eur. J. Pharm. Biopharm., v.59, p.147-154, 2005.

Recebido para publicação em 27 de julho de 2006. Aceito para publicação em 25 de abril de 2007. 